KARLSSON, J. L. (1970) The rate of schizophrenia in foster-reared close relatives of schizophrenic index cases. Biological Psychiatry. 2, 285-290.

Kiyama, R., Matsui, H. \& Oishi, M. (1986) A repetitive DNA family (Sau3 family) in human chromosomes: extrachromosomal DNA and DNA polymorphism. Proceedings of the National Academy of Sciences, 83, 4665-4669.

Lehrman, M. A., Russell, D. W., Goldstein, J. L. \& Brown, M. S (1986) Exon-Alu recombination deletes 5 kilobases from the low density lipoprotein receptor gene producing a null phenotype in familial hypercholesterolaemia. Proceedings of the National Academy of Sciences, 83, 3679-3683.

MAGer, D. L. \& HENTHORN, P. S. (1984) Identification of a retrovirus-like repetitive element in human DNA. Proceedings of the National Academy of Sciences, 81, 7510-7514.

Martin, M. R., Bryan, T., RAsheed, S. \& Kahn, A. S. (1981) Identification and cloning of endogenous retroviral sequences present in human DNA. Proceedings of the National Academy of Sciences, 78, 4892- 4896.

MUsich, P. R. \& DYkes, R. J. (1986) A long interspersed (LINE) DNA exhibiting polymorphic patterns in human genomes. Proceedings of the National Academy of Sciences, 83, 4854-4858.

Paulson, K. E., Deka, N., Schmid, C. W., Misra, R., Scindler, C. Rush, M. G., KADYK, L. \& LeINWAND, L. (1985) A transposonlike element in human DNA. Nature, 316, 359-361.

Sartorius, N., Jablensky, A., Korten, A., Ernberg, G., Anker, M., COOPER, J. E. \& DAY, R. (1986) Early manifestations and first-contact incidence of schizophrenia in different cultures. Psychological Medicine, 16, 909-928.

Singer, M. \& SKowronski, J. (1985) Making sense out of LINES: long interspersed repeat sequences in mammalian genomes. Trends in Biochemical Sciences, 10, 119-122.

\section{Barking Mad}

SIR: In reply to Dr Buchanan's letter (Journal, October 1987, 151, 562-563) we report two further cases of the 'barking mad'.

Case reports: (i) A 61-year-old German divorcee was admitted after having taken an overdose of a tricyclic antidepressant. She claimed it was a "cry for help", as she could no longer cope with her "mission". She described herself as being a dog (a German Shepherd), having known this since she barked instead of coughing 6 years previously following a cold. She showed her hand as proof of canine appearance, and also claimed that the transparent plaster over her CVP insertion site was a sign of moulting.

(ii) A 24-year-old unemployed man was admitted under Section 2 of the Mental Health Act. Six months prior to admission it was noted he was becoming increasingly withdrawn, self-neglectful and uncommunicative. On presentation he was mute, apart from turning his head from side to side and making clearly recognisable barking noises. His symptoms remitted within a month of treatment with anti-psychotic medication.

Unlike Dr Buchanan, we are unable to comment on the impact of such symptoms on the diplomatic service, but wonder whether, given the overrepresentation of this fairly unusual syndrome in our hospital, it could possibly be explained by the proximity of the Newham Health District to Barking and the Isle of Dogs.

R. SCHAPIRA D. H. ROY

Goodmayes Hospital

Barley Lane

Goodmayes

Essex IG3 $8 X J$

SIR: When I was a resident in psychiatry in 1974-75 at the Leeds General Infirmary, I was called late one evening by a rather dominant sister to see a "dog" in casualty. I told her I had no veterinary qualifications, but being an animal lover I made my way to casualty in a perplexed mood. I was pointed in the direction of a room in the casualty department that normally lacked any furniture, but had a mattress where, traditionally, alcoholics and psychiatric patients were examined. I saw a young man, properly dressed, between 18-22 years of age, on the mattress on his knees and elbows. When I started my usual psychiatric interview he continuously barked loudly, just like a dog, with no other types of noises. When I persisted on questioning, he suddenly said "I am a dog" and then barked again. Obviously I could not obtain further history. As psychiatric patients were on neurology wards in Leeds General Infirmary in those days, it was difficult to admit very disturbed patients. I avoided ringing Professor Hamilton at home and managed to admit the patient to High Royds Hospital.

My impression was that he was under some kind of family conflict and stress, and the intensity and frequency of barking was reduced when he knew he was going to be admitted. I later discovered that he had no previous history and settled rapidly without much pharmacological intervention and with psychosocial support.

Barking has been described as a part of a clinical picture in patients with Tardive Tourette syndrome (Stahl, 1980), and in Gilles de la Tourette's syndrome (Abuzzahah, 1982). Involuntary noises are not uncommonly heard in patients with severe tardive dyskinesia due to the involvement of muscles of expiration. It is also not uncommon for schizophrenic and severely agitated depressives to make some strange noises. Pure barking as a clinical symptom in the absence of any other associated illness is extremely uncommon, and is most probably stress-related and under voluntary control.

Professorial Unit

K. S. VADDADI

Larundel Hospital

PO Box 101

Bundoora

Victoria 3083, Australia 


\section{References}

Abuzzahah, S. R. F. S. (1982) Gilles de la Tourette syndrome or multiple tic disorder. In Extraordinary Disorders of Human Behaviour (eds Claude T. H. Friedmann and Robert A. Faguet). New York: Plenum Press.

STAHL, S. M. (1980) Tardive Tourette syndrome in an autistic patient after long-term neuroleptic administration. American Journal of Psychiatry, 137, 1267-1269.

SIR: I haven't encountered a barking patient, but I vividly recall one who mooed.

Again, like Dr Buchanan's patient it was a lady in late middle age who was admitted to hospital for assessment following her complaint that she was unable to control an urge to make a mooing noise during normal speech. I saw her as a trainee clinical psychologist, and found that she, too, exercised some voluntary control, but she asserted that she was unable to control the behaviour completely, since she was liable to moo in most embarrassing circumstances.

Unfortunately my training soon required me to move from this hospital, so I am unable to report the outcome of the assessment, or whether any treatment was effective.

If any other clinicians have encountered similar symptoms, might this represent a syndrome which could be called the MacDonald syndrome - or, in the senile, the Old MacDonald syndrome?

Greybury House

Bridge Street

Walsall WS1 1ET

Allan J. Norris

SIR: A case was described recently in these columns of a patient whose principal symptom was barking. What is less well-known is that barking can be an effective form of therapy. I myself have used the technique on several occasions. The patient must be fully conscious, agitated, obstreperous, and canine. It would be interesting to know if psychoanalytical or behavioural explanations are more appropriate.

1 Helena Road

BERNARD INEICHEN

Plaistow

London E13 ODZ

\section{Screening for Hepatitis B in the Mentally Handicapped}

SIR: The importance of screening for hepatitis B in both the hospital and community population of the mentally handicapped was pointed out by Jancar (Journal, September 1987, 151, 417-418). As an infection control nurse, I recently compiled a study evaluating screening of patients before movement from hospital into the community, and further, to what degree vaccination is offered to patients and staff.

A questionnaire was sent to 25 Mental Handicap Units in the United Kingdom, with $76 \%$ response. The findings show that $37 \%$ of patients are not screened for hepatitis B markers, $37 \%$ are screened if in contact with a known carrier, $21 \%$ on admission, and only $5 \%$ of patients are screened before transfer into the community. It was established that vaccine was given to $32 \%$ of patients and $53 \%$ of staff having contact with a known carrier.

While only a selective sample, the study demonstrates that action is taken generally only in response to known carriers. Locally, screening for hepatitis B markers is considered a priority for those patients whose transfer into the community is imminent; moreover, a policy of screening all patients is in operation to enable preventative measures of infection control to be undertaken.

The financial implications of implementing this plan to screen and vaccinate patients and staff when appropriate are recognised. However, the recent reduction in cost of the hepatitis $B$ vaccine should encourage a more appropriate response to this important issue.

\section{Groby Road Hospital \\ Groby Road \\ Leicester LE3 9QE}

R. CARTER

\section{Maternity Blues and Post-Partum Euphoria}

SIR: I think Valerie Levy (Journal, September, 1987, $151,368-372$ ) is right in maintaining that the maternity blues is related to the dysphoria which follows surgery and other stress, but she has omitted to mention an important psychological factor-postpartum euphoria. This, in my view, explains the difference between childbirth and surgery, and the gap between delivery and the onset of the blues.

The mood changes which follow hysterectomy have been studied by Kendell et al (1984) and Kennedy \& Gath (1986): there is a steady fall from day one to day ten. Those following childbirth are similar from the fifth day onwards. The difference between the two is that depression scores are low during the first four days after delivery, rising sharply on the fifth day. These findings are compatible with a two-factor theory of the blues, which results from the combined effects of post-partum euphoria and posttraumatic dysphoria. In other words, the relief and joy which usually follow delivery protect against and mask the depression, tearfulness, irritability, and tiredness which would normally follow such an 